\title{
Quality assessment of vegetable oil industry effluents in Port Harcourt, Rivers State, Nigeria
}

\author{
A. W. Verla ${ }^{1, *}$, E. N. Verla ${ }^{2}$, P. Adowei ${ }^{1}$, A. Briggs ${ }^{1}$, M. Horsfall Jnr ${ }^{1}$ \\ ${ }^{1}$ Department of Pure and Industrial Chemistry, University of Port Harcourt, Choba, Nigeria \\ *Tel: 07069288937 \\ ${ }^{2}$ Department of Industrial Chemistry, Madonna University Elele Campus, Rivers State, Nigeria \\ *E-mail address: Verngo@yahoo.com
}

\begin{abstract}
Five composite samples of waste water were collected from waste water tank of a vegetable oil refining company and were analyzed for physiochemical characteristics, heavy metal and organic pollutants. Physicochemical determinations were done according to standard methods; heavy metals were determined by use of Atomic Absorption Spectrophotometer method while organic pollutants were determined by Gas chromatography system HP 6890 series. Sulphate was determined by vanadomolybdophosphoric acid method while phosphates and chlorides were determined by argentometric method. Results reveal that effluent $\mathrm{pH}(4.67 \pm 0.015)$, salinity $(125 \pm 4.50 \%)$ and $\mathrm{BOD}_{5}(17.83 \pm 1.70 \mathrm{mg} / \mathrm{l})$ were bellow WHO standard whereas TDS $(127.7 \pm 5.77 \mathrm{mg} / \mathrm{l})$, TSS $(563.6$ $\pm 3.15 \mathrm{mg} / \mathrm{l})$ and COD $(3959 \pm 3.8 \mathrm{mg} / \mathrm{l})$ were above WHO standards. Heavy metal pollution index (0.31) showed no multi-element contamination arising from effluent. The degree of contamination (1.84) showed that the effluent has a moderate polluting potential. Lower molecular weight PAHs showed a significant difference even though most of the organic compounds in vegetable oil refinery wastewater showed good biodegradability that varied weekly. Therefore there is either no treatment or an in effective treatment of the effluents. This could result to serious environmental problems in the near future.
\end{abstract}

Keywords: Physicochemical; wastewater; biodegradability; pollutants; indices

\section{INTRODUCTION}

Effluents has been linked to numerous environmental pollution problems ranging from long term environmental degradation to increased incidence of water borne disease [1]. Effluents are waste water, treated or untreated flowing out of a plant sewer or industry. Effluents have been known to reduce the wholesomeness of the environment especially when the pollution status exceeds that of an acceptable level [2].

Effluent discharge is the most devastating pollution source because pollution of water, air and land are very closely interrelated and if not properly managed, pollutants from one medium could be transferred to other media [3]. In order to address this problem most countries have set up effluent discharge standards and regulations as well as enforcement 
agencies $[4,5]$. Nigeria as a developing nation applies anticipative and preventive strategies that avoid expensive and intensive environmental control measures [6,7].

Pretreatment of oilseeds is a major step in refining and modification of oils. During these processes by-products and wastes are formed. Vegetable oil facilities require significant amounts of water for crude oil production, cooling water, chemical neutralization processes, and subsequent washing and deodorization [10].

The operating conditions and processes carried out influence the amount and characteristics of the by-products and wastes formed. Despite the use of these methods, disposal and waste treatment still remain a major challenge for the vegetable oil industry. One of the contributing factors as to why such wastewaters are difficult to treat is the complexity of their sources.

Despite these hazards associated with these waste, many industries still dispose their waste indiscriminately in water bodies [11]. This habit has been linked directly or indirectly to the cost of treatment of effluents prior to discharge into the environment [12]. Therefore, environmental pollution monitoring has become important in detecting where serious pollution is occurring and the pollutants involved. Such studies are needed not just as baseline data but could guide environmental policies. It is against this background that the present research focuses on the physiochemical characteristics, heavy metal and organic pollutants of vegetable oil industry effluents. Results could be useful in examining the extent of effluent treatment by the company and assessing the degree of compliance with environmental safety regulations [13].

\section{EXPERIMENTALS}

Four grab samples of 2 litres each were collected from first effluent tank at a company in Port Harcourt. Samples were collected at points where wastewater was well mixed avoiding points of settling of debris and larger solids. Samples were refrigerated at $4{ }^{\circ} \mathrm{C}$ and were analysed before 48 hours according to standard procedures.

\section{1. Determination of physicochemical characteristics}

Physicochemical characteristics determinations were carried out according to the Standard Methods for the Examination of Water and Waste water (APHA, AWWA and WEF 1998) except those detailed here [14]. Analytically pure grade reagents were purchased from Fin lab Ltd Owerri, and used in all experiments.

\section{2. Determination of Phosphate}

This was determined by vanado-molybdo-phosphoric acid colorimetric method as described by Ademoroti [15]. Absorbance values were measured at $490 \mathrm{~nm}$ using spectrophotometer (Jenway $6505 \mathrm{UV} / \mathrm{vis}$ ). By extrapolation from the standard curve, the phosphate was calculated using the formula:

$$
\mathrm{PO}_{4}{ }^{3-}(\mathrm{mg} / \mathrm{l})=\frac{D(m g) x 1000}{m l \text { of sample }}
$$

where; $\mathrm{D}$ is dilution factor 


\section{3. Determination of Salinity}

The electrical conductivity method was used in which reagents and apparatus was the same. The conductivity meter was calibrated using the $1000 \mu \mathrm{S} / \mathrm{cm}$ conductivity standard. The mode key was pressed until the parts per thousand units was displayed. The probe was then rinsed with some portion of sample and immensed into the sample avoiding trapping of air bubbles around the temperature sensor. The reading was allowed to stabilize before recording [15].

\section{4. Determination of Biochemical Oxygen Demand}

BOD readings of effluent were measured using the Lovibon BOD IR Sensomat. A 10 $\mathrm{ml}$ sample volume was collected into the $500 \mathrm{ml}$ BOD flask. The IR-pressure sensor (a measurement device) was connected to the BOD flask and the start button on the Sensomate depressed. Then the IR sensor was logged into the BOD-Sensomat and reading converted directly to $\mathrm{mg} / \mathrm{l}$ of BOD and value read and recorded.

\section{5. Determination of Chemical Oxygen Demand}

The apparatus used in this study was PCcheckit COD Vario (Lovibond,Germany) consisting of PCcheckit COD Vario photometer and COD reactor ET 108. A $20 \mathrm{ml}$ effluent sample was put into contact with the acid solution, and held at $148^{\circ} \mathrm{C}$ for $2 \mathrm{hrs}$. After cooling the sample was then placed into sample cell of the PCcheckit COD Vario photometer. The colour of the samples varied from orange to dark green indicating COD value of the range $15-3800 \mathrm{mg} / \mathrm{l}$. For every sample the COD was then read off from the display screen in $\mathrm{mg} / \mathrm{l}$.

\section{6. Determination of heavy metals}

This was done by use of Pye Unicam 968 model Atomic Absorption Spectrophotometer method. Heavy metal pollution index of the effluents was calculated by averaging the ratios of the heavy metal concentrations to their permissible levels [16].

\section{7. Determination AHC, PAH and (TPH)}

An aliquot of each of the samples was extracted by transferring into a separatory funnel and $10 \mathrm{ml}$ of pentane (extraction solvent) was added. The solvent extract was carefully cleared up and concentrated to $1 \mathrm{ml}$ for analysis. $1 \mu \mathrm{l}$ of the concentrated sample was rapidly injected into the column. After separation between the gas and liquid phases, the sample was automatically detected as it emerges from the column gas chromatograph used was a HP 6890 series (Hewlett Packard, USA) equipped (at a constant flow rate) with FID detector at 38.3 minutes run times.

\section{8. Statistical Analysis}

Data obtained from this study were analysed using the statistical package for social sciences (SPSS) version 18.0 for windows. Independent sample t-test and analysis of variance (ANOVA) were used to compare means, and values were considered significant at $\mathrm{p}<0.05$. Results were reported as mean $\pm \mathrm{n}$ SDV for triplicate analysis where appropriate 


\section{RESULTS AND DISCUSSION}

Table 1 shows mean values of physiochemical characteristics of vegetable oil industry effluents analyzed for the company. The $\mathrm{pH}(4.67 \pm 0.015)$ showed that the effluent was acidic. Production of vegetable oil includes many technological processes and the effluent mainly comes from degumming, deacidification and deodorization steps [17].

Table 1. Mean values of physicochemical characteristics of VOIE.

\begin{tabular}{|c|c|c|c|}
\hline Parameters & Mean \pm n SDV (mg/l) & WHO, 1994 & Comment \\
\hline $\mathrm{pH}$ & $4.67 \pm 0.015$ & $6-9$ & Below effluent \\
\hline Cond. $(\mu \mathrm{S} / \mathrm{cm})$ & $253 \pm 1.15$ & - & - \\
\hline Sal $(\%)$ & $125 \pm 4.50$ & 600 & Above standard \\
\hline TDS $(\mathrm{mg} / \mathrm{l})$ & $127.7 \pm 5.77$ & 2000 & Above standard \\
\hline TSS $(\mathrm{mg} / \mathrm{l})$ & $563.6 \pm 3.15$ & $30-50$ & Above standard \\
\hline BOD $5(\mathrm{mg} / \mathrm{l})$ & $17.83 \pm 1.70$ & 50 at $20{ }^{\circ} \mathrm{C}$ & Below standard \\
\hline Permanganate value & $16.28 \pm 5.50$ & - & - \\
\hline TOC $(\mathrm{mg} / \mathrm{l})$ & $3851.37 \pm 4.41$ & - & Above standard \\
\hline COD $(\mathrm{mg} / \mathrm{l})$ & $3959 \pm 3.82$ & 250 & - \\
\hline Sulphates $(\mathrm{mg} / \mathrm{l})$ & $684 \pm 5.60$ & - & - \\
\hline Phosphates $(\mathrm{mg} / \mathrm{l})$ & $890 \pm 3.50$ & - & \\
\hline
\end{tabular}

Table 2. Mean concentrations of selected metals and contamination factors (Cf).

\begin{tabular}{|c|c|c|c|}
\hline Metal & Mean \pm SD & FEPA1991standards (mg/l) & Cf \\
\hline $\mathrm{As}$ & $0.0010 \pm 0.0001$ & 0.01 & 0.01 \\
\hline $\mathrm{Ni}$ & $0.0010 \pm 0.0001$ & 1 & 0.001 \\
\hline $\mathrm{Co}$ & $0.347 \pm 0.017$ & 1 & 0.347 \\
\hline $\mathrm{Zn}$ & $0.595 \pm 0.012$ & 1 & 0.595 \\
\hline $\mathrm{Pb}$ & $0.0010 \pm 0.0001$ & 1 & 0.001 \\
\hline $\mathrm{Cr}$ & $0.23 \pm 0.020$ & 1 & 0.23 \\
\hline $\mathrm{Cd}$ & $0.00010 \pm 0.0001$ & 1 & 0.0001 \\
\hline
\end{tabular}


Table 3. Mean values of aliphatic hydrocarbons in VOIE samples.

\begin{tabular}{|c|c|c|c|}
\hline Total Aliphatic HC & $\begin{array}{c}\text { Conc. metal } \\
(\mathrm{mg} / \mathrm{l})\end{array}$ & $\begin{array}{c}\text { Level of } \\
\text { Significance }\end{array}$ & Decision \\
\hline Nonane & $0.0117 \pm 0.00306$ & 0.021 & Not Significant \\
\hline Decane & $0.0070 \pm 0.00265$ & 0.021 & Significant \\
\hline Dodecane & $0.0103 \pm 0.00153$ & 0.490 & Not significant \\
\hline Teradecane & $0.0220 \pm 0.00300$ & 0.000 & Significant \\
\hline Hexadecane & $0.0143 \pm 0.00404$ & 0.173 & significant \\
\hline Octadecane & $0.0117 \pm 0.00208$ & 1.000 & significant \\
\hline Nonadecane & $0.0137 \pm 0.00306$ & 30.3 & significant \\
\hline Eicosane & $0.0107 \pm 0.00153$ & 604 & Not significant \\
\hline Docosane & $0.0120 \pm 0.00361$ & 862 & Not significant \\
\hline Tetracosane & $0.0150 \pm 0.00100$ & 091 & Not significant \\
\hline Hexacosane & $0.0093 \pm 0.00153$ & 231 & Not significant \\
\hline Octacosane & $0.0000 \pm 0.00000$ & 000 & - \\
\hline Triacosane & $0.0000 \pm 0.00000$ & 000 & - \\
\hline Heatriacosane & $0.0000 \pm 0.00000$ & 000 & - \\
\hline
\end{tabular}

Table 4. Mean concentrations of polynuclear aromatic hydrocarbon (PAH) content.

\begin{tabular}{|c|c|c|c|c|}
\hline PAH & Conc. $(\mathbf{m g} / \mathbf{l})$ & $\begin{array}{c}\text { Standards } \\
(\mathbf{m g} / \mathbf{l})[\mathbf{2 1}]\end{array}$ & $\begin{array}{c}\text { Level of } \\
\text { sign. }\end{array}$ & Decision \\
\hline Naphtalene & $0.0053 \pm 0.00351$ & 0.001 & 0.16 & Significant \\
\hline 2-methylnaphtalene & $0.0037 \pm 0.00208$ & 0.001 & 0.02 & Significant \\
\hline Cenaphthalene & $0.0047 \pm 0.00115$ & 0.001 & 0.091 & Significant \\
\hline Acenaphthalene & $0.037 \pm 0.012$ & 0.001 & 0.015 & Significant \\
\hline Florene & $0.0257 \pm 0.00404$ & 0.001 & 0.034 & Significant \\
\hline Phenathrene & $0.0520 \pm 0.00346$ & 0.001 & 0.035 & Significant \\
\hline Antracene & $0.0617 \pm 0.00702$ & 0.001 & 164 & N.S \\
\hline
\end{tabular}




\begin{tabular}{|c|c|c|c|c|}
\hline Flourathane & $0.0053 \pm 0.00351$ & 0.01 & 034 & Significant \\
\hline Pyrene & $0.0030 \pm 0.00100$ & 0.01 & 0.000 & N.S \\
\hline Benzo(a)Anthra & $0.0000 \pm 0.00000$ & 0.01 & 0.000 & N.S \\
\hline Benzo(a)Pyrene & $0.0000 \pm 0.00000$ & 0.1 & 0.000 & N.S \\
\hline Benzo(a)Flourathane & $0.0000 \pm 0.00000$ & 0.01 & 0.000 & N.S \\
\hline Indeno-123-pyrelene & $0.0000 \pm 0.00000$ & 0.1 & 0.000 & N.S \\
\hline Dibenzo(a.b)Anthacene & $0.0000 \pm 0.00000$ & 5.00 & 0.000 & N.S \\
\hline Benzo(g.h.i)pyrene & $0.0000 \pm 0.00000$ & 1.00 & 0.000 & N.S \\
\hline
\end{tabular}

Data reported as mean $\pm \mathrm{nSDV}$ for $\mathrm{n}=3$; N.S: Not significant;

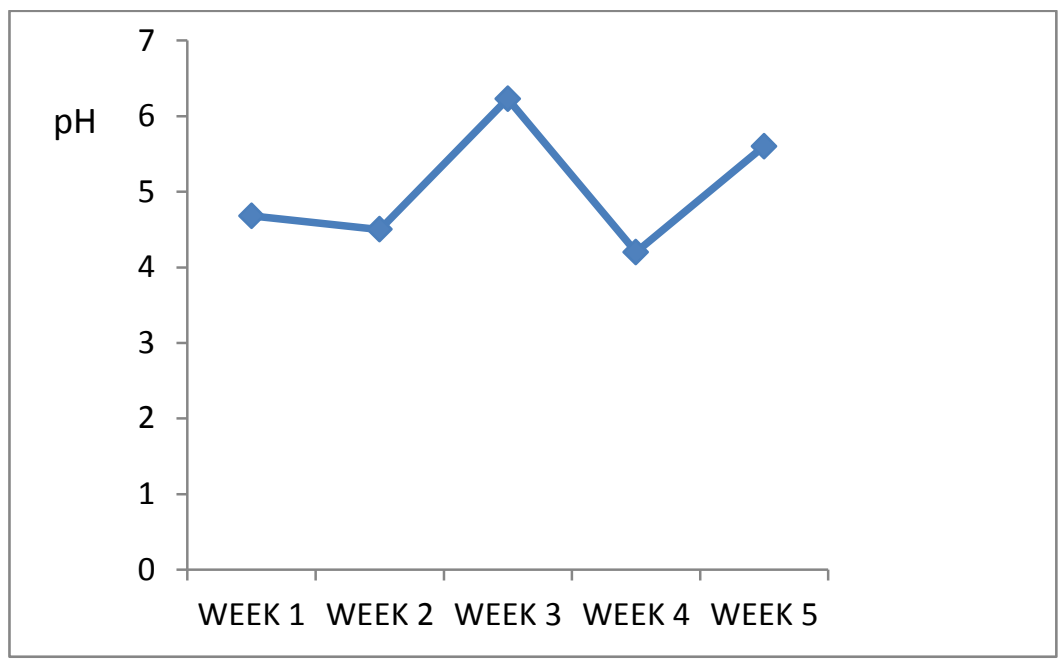

Figure 1. Variation of weekly $\mathrm{pH}$ of VOIE.

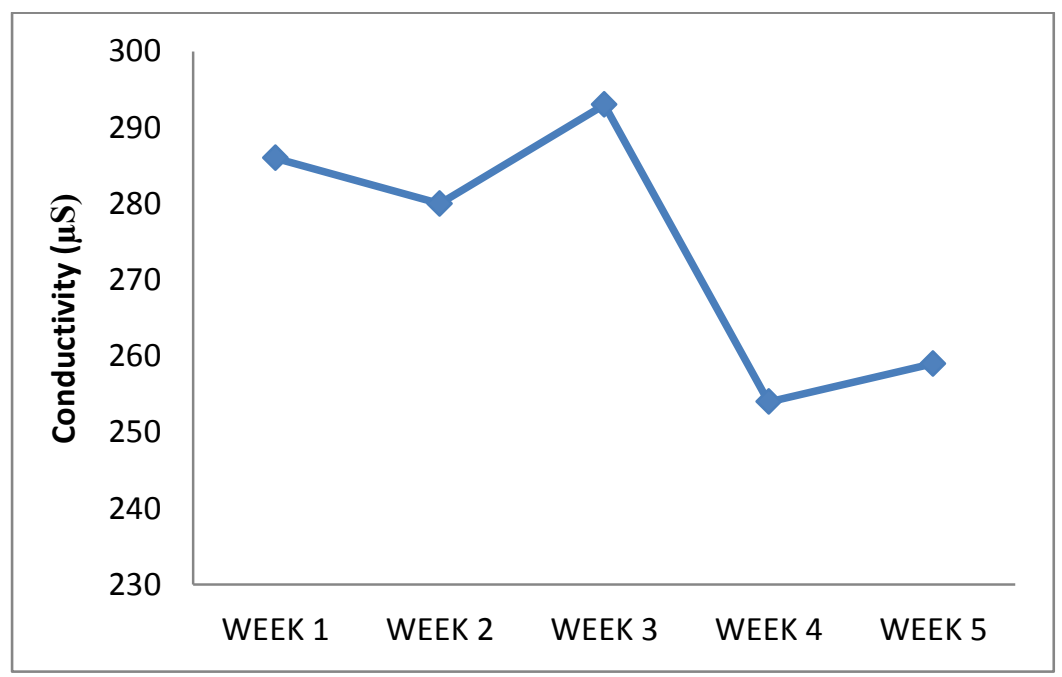

Figure 2. Variation of conductivity of VOIE. 


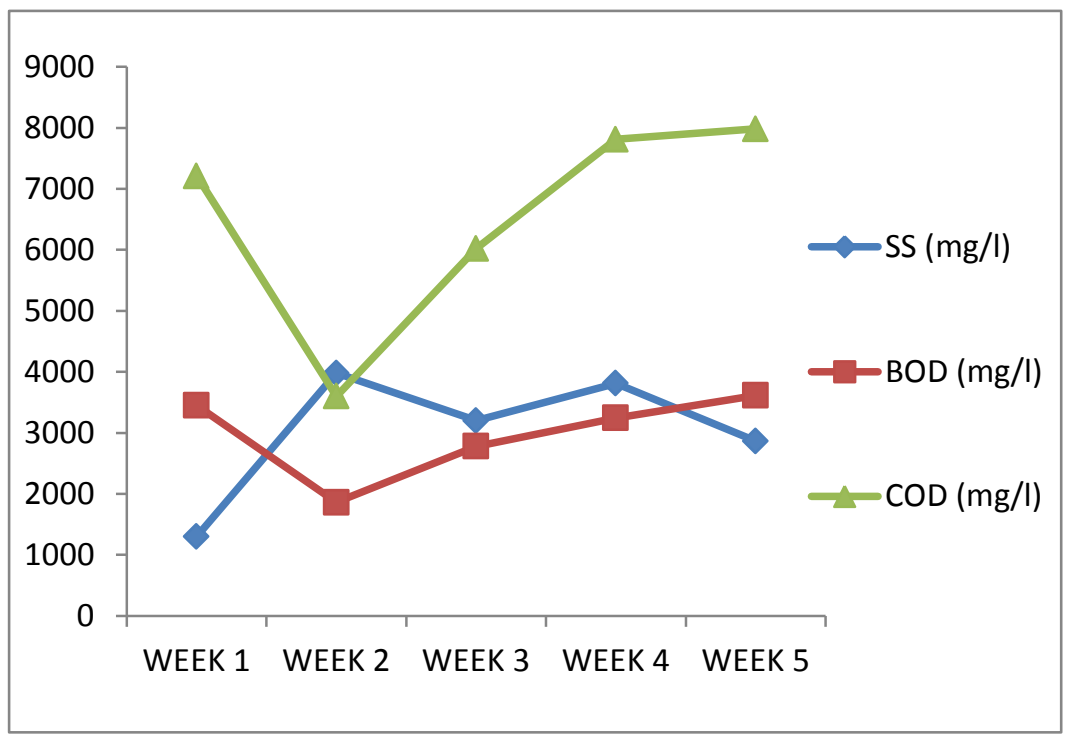

Figure 3. Variation of $\mathrm{SS}(\mathrm{mg} / \mathrm{l}), \mathrm{BOD}_{5}(\mathrm{mg} / \mathrm{l}), \mathrm{COD}(\mathrm{mg} / \mathrm{l})$ of VOIE.

As part of refining process, sulphuric acid is added to the soap stock to cause separation of free fatty acid from the medium. This is the major cause of the effluent being acidic [18]. The conductivity of VOIE was $253.3 \pm 1.17 \mu \mathrm{S} / \mathrm{cm}$ all other parameters were far above the WHO standard FEPA standards and EHS guidelines, while BOD $_{5}(18.33 \pm 1.70 \mathrm{mg} / \mathrm{l})$ was only higher than WHO standard, COD $(3959.53 \pm 3.82 \mathrm{mg} / \mathrm{l})$ was 180 percent higher than the WHO standards. Sulphates and phosphates were $684 \pm 5.60$ and $890 \pm 3.50 \mathrm{mg} / \mathrm{l}$ respectively, again higher than WHO standards. Euthrophication, the consequences of much phosphate has been emphasized by many researchers. The high values phosphate may be due to fertilizer applications during the cultivation of oil fruits [19]. There is equally a high amount of organic matter as indicated by total organic carbon $351.37 \pm 441(\mathrm{mg} / \mathrm{l})$.

Table 2 shows the selected metal content of VOIE analyzed. Seven Heavy metals were selected based on their toxicity to organism and the possibility of being found in vegetable oil industry effluents. The adverse effects of these metals are well documented in literature [20]. Zinc, Cobalt and chromium had low concentrations. The adverse effects of these heavy metals include retardation of growth, decrease longevity, detrimental changes in reproductive cycles, morbidity, pathological changes and symptoms of chronic diseases and formation of tumors. Arsenic lead and cadmium and nickel were found to be about 100 times less than FEPA 1991 standards. The heavy metal pollution index (HMPI) was according to equation...(2).

$$
H M P I=\frac{[A s]}{P L}+\frac{[N i]}{P L}+\frac{[P b]}{P L}+\frac{[Z n]}{P L} \frac{[C o]}{P L}+\frac{[C r]}{P L}+\frac{[C d]}{P L} / 7 \ldots \ldots \ldots \ldots .2
$$

PL: permissible levels for various metals; 7 represents the no. of metals involved.

The value obtained for HMPI was 0.311 , showing that there is less possibility of multielement contamination as a result of dumping VOIE in an environment. Pollution indexes of less than 1 show no risk of pollution, but above 1 shows possible multi-element contamination by source or of an environment [21]. 
The contamination factors $(\mathrm{Cf})$ and degree of contamination $\left(\mathrm{C}_{\mathrm{d}}\right)$ were calculated according to equations 2 and 3 respectively

$$
\begin{aligned}
& \mathrm{C}_{\mathrm{f}}=\mathrm{C}_{\mathrm{s}} / \mathrm{C}_{\mathrm{b}} \ldots \ldots \ldots \\
& \mathrm{C}_{\mathrm{d}}=\sum \mathrm{C}_{\mathrm{f}} \ldots \ldots \ldots \ldots
\end{aligned}
$$

Values of contamination factors (Cf) ranged from Cadmium (0.0001) to Zinc (0.595) and degree of contamination $\left(\mathrm{C}_{\mathrm{d}}\right)$ of effluent was only 1.84.These are considered as very low contamination factors however the degree of contamination cannot be overlooked over time. The source of metals in VOIE could be ware and tear of process equipment and metal contents of oils. These sources are usually low and are therefore reasons for low contamination factors in the present study.

Table 3 shows some aliphatic hydrocarbons found in vegetable oil industry effluents. The values of aliphatic hydrocarbons (PAHs) in VOIE showed that nonane $(0.0120 \pm 0.003)$; decane $(0.007 \pm 0.003)$; dodecane $(0.010 \pm 0.001)$; tetradecane $(0.022 \pm 0.003)$ and hexadecane $(0.014 \pm 0.004)$ were significant; while octadecane $(0.012 \pm 0.002)$; nonadecane $(0.014$ $\pm 0.003)$; eicosane $(0.011 \pm 0.002)$; hocosane $(0.012 \pm 0.004)$; tetracosane $(0.015 \pm 0.001)$ and hexacosane $(0.009 \pm 0.002)$ were not significant. However octacosane, triacontane and hexatriacontane were not detected.

Table 4 shows 15 PAHs analysed and concentrations compared with standards reported by in literrature. Anthracene $(0.0617 \pm 0.007)$ was highest followed by phenathrene $(0.052$ $\pm 0.004)$ while naphthalene, 2-methyl naphthalene, and pyrene ranged from $0.003 \pm 0.001$ to $0.026 \pm 0.004$. Benzo(a)anthracene, benzo(a)pyrene, benzo(a)flourathane, indeno-123pyrelene, dibenzo(a.b)anthacene, benzo(g.h.i)pyrene were absent from the effluent. These components are carcinogenic and have been tagged hazardous in many environmental pollution guidelines. All other PAHs present exceeded the FEPA guidelines. The pollution index in terms of PAHs (26.88) was very high, indicating high pollution potential. The values of naphthalene, 2-methylnaphthalene, cenanphthalene, acenaphthene, flourene, phenanthrene and anthracene were all significant at $\mathrm{P}<0.05$ while the rest of the PAHs showed no significance. PAHs constitute a wide class of compounds consisting of two or more fused benzene rings.

The variation of contents of sulfates, phosphates and chlorides was also observed. As a result of increasing population and industrial expansion waste waters have continually been on the increase in volume, especially in developed economies. Industrial effluent usually contain contaminants such as heavy metals, cyanide, toxic organics, nitrogen phosphorous, phenols, suspended solids, colors and turbidity [22].

PAH are of concern for three main reasons: firstly, low molecular weight PAH can be directly toxic to marine animals; secondly, because metabolites of some of the high molecular weight PAH are potent animal and human carcinogens e.g benzo[a]pyrene; thirdly, low molecular weight PAHs can cause taint in the fish and shellfish, resulting in consumer rejection of the product and an associated loss in consumer confidence which has an obvious impact on the fish and shellfish industries. Carcinogenic activity is closely related to structure, however and other PAH with a molecular weight of $252 \mathrm{Da}$, and so isomeric with benzo[a]pyrene, (benzo[e]pyrene, perylene, and four isomers of benzofluoranthene) are either much less potent or inactive. There are therefore two problems with comparing and assessing data, as different suites of PAH can be (and are) analyzed in fish and shellfish tissues following different incidents, and simple summations of the concentrations of those 
compounds do not reflect the risk to consumers. In this respect, $\mathrm{BOD}_{5} / \mathrm{COD}$ ratios of the untreated and treated wastewater were calculated in order to evaluate the potential biodegradability of the organic compounds in the wastewater. Results illustrated in fig.4 shows that the value of $\mathrm{BOD}_{5} / \mathrm{COD}$ was greater than 0.5 , suggesting that organic compounds present in the effluent are biodegradable [23]. However, the relative biodegradabilities of the wastewater samples fluctuated weekly. Other researchers attribute fluctuation of vegetable oil wastewater characteristics to different oils refined and to operating conditions and processes [24]. Wastewater characteristics are not only influenced by raw materials and products processed, but also by water used in washing procedures during and after the production [25]. These factors apparently influenced the observed variation in the $\mathrm{BOD}_{5} / \mathrm{COD}$ values of each wastewater sample. In Fig. 4, the $\mathrm{BOD}_{5} / \mathrm{COD}$ values for wastewater were high. Therefore, acid wastewater, which is characterized by a high rate of oxidizable substances, fats, fatty acids, sulfates and phosphates [26], as well as low pH values (Fig. 3), would be less biodegradable. Therefore, results also suggest that physicochemical treatment processes carried out had both negative and positive influences on the biodegradability of the wastewater. Wastewater had the highest $\mathrm{BOD}_{5} / \mathrm{COD}$ values at the fifth week, but the values were significantly low from the second to the fourth week.

PAH data is often reported as a combination of individual parent compounds and groups of substituted PAH of between 2 and 5 rings often in a list of between 35 and 45 PAH compounds/groups being presented following an individual analysis. Although the smaller, 2to 4-ring PAH compounds are of little concern with regards to carcinogenicity, many of the larger PAH compounds are potential carcinogens [27].

Figure 1 show the weekly variation of $\mathrm{pH}$ of effluents, the $\mathrm{pH}$ of VOIE varied widely between all five weeks. The effluent was acidic and showed highest $\mathrm{pH}$ of 6.8 at the third week.

Figure 2 represent conductivity followed a similar trend with week 3 having highest conductivity where as weak 4 showed lowest conductivity. This agrees with values of TDS in table1.

Figure 3 shows weekly variation of $\mathrm{SS}, \mathrm{BOD}_{5}$ and $\mathrm{COD}$. Weak one showed a very high value of COD in effluent. This drop in week two to be the lowest for all five weeks, then steadily rosed through week 3 and then week five having the highest COD in the effluent. In all five weeks $\mathrm{COD}$ values were usually higher than $\mathrm{BOD}_{5}$. All though the five weeks the suspended solid and $\mathrm{BOD}_{5}$ showed a close similarity but only in week one and five that $\mathrm{BOD}_{5}$ was higher than SS. In a similar study Verla et al [28] remarked that $\mathrm{BOD}_{5}$ is usually higher than TSS. Results presented for samples taken over a 5 weeks period are in agreement with the remark. This could be due to the fact that organic substance that are measurable by $\mathrm{BOD}_{5}$ may not all be suspended but dissolved in the aqueous effluents. Each week was represented by a mean of three independent samples. These mean $\mathrm{BOD}_{5}$ and $\mathrm{COD}$ values confirm that the vegetable oil refinery wastewater has a varying high organic pollution load.

\section{CONCLUSIONS}

In conclusion, major characteristics of concern exhibited characteristic variations and complexity within weekly samples. Despite its complexity and variation all samples showed good biodegradability. Results showed that vegetable oil industry effluents is an acidic complex aqueous media composed of widely-distributed organic and inorganic materials dissolved as well as suspended in water. The organic contaminants leading to high $\mathrm{BOD}_{5}$ and 
COD values are possibly due to soluble and stable emulsified organic matter, which the physicochemical treatment system does not remove from the effluents. Even though the heavy metal pollution index suggests no multi-element contamination arising from this effluent, there is the need for preventive measure to be put in place.

\section{Acknowledgement}

We express deep gratitude to the Director; Centre for Energy Research, University of Nigeria Nsukka, for the use of certain scientific instruments and the expertise of Mr. Ofomota Anthony Chibuzo the chemical analyst and Engineer Clement of Federal Environmental Laboratory, Imo State.

\section{References}

[1] A. O. Oladele, African Journal of Environmental Science and Technology 1(2) (2007) 1.

[2] NESREA. National Environmental Standard and Regulatory Enforcement Agency Federtal Republic of Nigeria Official Gazette. Lagos, 2011.

[3] A. Krause. Textbook and Manual of Wastewater Technology: Organically contaminated wastewaters from the food processing industry, Vol. 5; Verlag fur Architektur und Technische Wissenschaften, Berlin, 1985; 49-54.

[4] R. A. Pandey, P. B. Sanyal, N. Chattopadhyay, S. N. Kaul, Resources Conservation and Recycling 37(2) (2003) 101-117.

[5] O. Osibanjo, Federal Environmental Protection Agency, FEPA Monograph 1996; 35-59.

[6] S. N. Kulshreshtha, Water Resources Management 12(3) (1998) 167-184.

[7] N. Manivasaka, Sakthi publication, Kovaipudur coimbatone, 1987, 50.

[8] K. B. Chipasa, K. K. Chin, K. K. Wong, Water Research 15 (1981) 1087.

[9] W. C. Seng, J. Amer. Oil Chem. Soc. 57 91980) 926A.

[10] J. M. Okuo, A. C. Ozioko, J. Chem. Soc. Nig. 26(1) (2001) 60-65.

[11] USEPA, EPA/600/R 93/089, United States Environmental Protection Agency, 1993.

[12] APHA, AWWA and WEF. Standard Methods for the Examination of Water and Wastewater. 20th edition, Clesceri, L.S., Greenberg, A.E. and Eaton, A.D. (Editors), APHA, AWWA, WEF, Washington DC. 1998.

[13] V. D. Heinrich, A. Krause, I Sekoulov, Fat Sci. Technol. 94 (1992) 28.

[14] P. Becker, D. Koster, M. N. Popov, H. Maaki, Water Research 33 (1999) 653.

[15] Ademoroti C. M. A. (2006). Standard Methods for Water \& Effluents Analysis. 1st Edition. Foludex press limited, Ibadan, Nigeri

[16] M. J. Boyer, J. Amer. Oil Chem. Soc. 61 (1984) 146, 297.

[17] P. C. Okoye. V. N. Okolo, F. D. C. Ozoigbo, World Journal of Biotechnology 4 (2003) 678-688.

[18] G. Choffel, J. Amer. Oil Chem. Soc. 53 (1976) 446. 
[19] M. Waziri, V. O. Ogugbuaja, American Journal of Scientific and Industrial Research 1(1) (2010) 76-80.

[20] S. C. Eziuzor, G. C. Okpokwasili, Nigerian Journal of Microbiology 23(1) (2009) 1777-1791.

[21] C. M. A. Ademoroti. Standard methods for water and Effuents Analysis. Ibadan: Foludex Press Ltd. 1996; 44-54.

[22] V. O. Ogugbuaja, R. Kinjiir, Res. J. Sci. 7(1-2) (2001) 1-6.

[23] E. R. Rene, M. B. Saidutta, International Journal of Environmental Research 2(2) (2002) 183-188.

[24] P. Shegunova, K. Terytze, I. Atanassov. Proceeding of International Workshop, Sofia, Bulgaria, 30 September-3 October, 2001; Terytze, K.; Atanassov, I., Eds.; 2001; 202-209.

[25] B. Škrbić, N. Miljević, J. Environ. Sci. Health A. 37 (2002) 1029-1039.

[26] B. Škrbić. Faculty of Technology, Novi Sad, Serbia, 2003.

[27] T. Spitzer, J. Chromatogr. A. 643 (1993) 305-309.

[28] A. W. Verla, P. J. C. Nwosu, E. N. Verla, Tropical Journal of Biomedical and Allied Science Research 2(1) 137(2008) 140. 